\title{
Where is the business? A study into prominent items of the Vertical Farm Business Framework
}

\author{
S. Allegaert, E.F.M. Wubben and G. Hagelaar \\ Business Management and Organisation, Wageningen University, Wageningen, The Netherlands
}

\begin{abstract}
Summary
There is scarce public knowledge regarding comparable feasible business formats. This paper develops a Vertical Farm Business Framework to raise our understanding of the major, generic items in the development of Vertical Farms as commercial endeavours. The huge variety of the research objects and the early stage of research into business formats makes exploratory research the suited approach. A review of the related literature is complemented by a validation by 25 insiders from Europe and North America. When it comes to governance and cooperation good partnerships are deemed fitting, especially with distribution centres and specific food sectors. Regarding organization, there is optimism on drastic costs decreases due to advances in lighting, HVAC, and automation. Finally, as part of the enabling environment, the social value of Vertical Farms is not clear, and legal issues were not found to be a major concern, apart from zoning issues. A prominent theme became the need for properly trained employees. In sum, establishing a commercially viable vertical farm remains a complex matter, where strategic decision can benefit from a Vertical Farm Business Framework.
\end{abstract}

\section{Introduction}

Food-related challenges, such as ongoing population growth and urbanisation, climate change, and worries about food safety and shortage of arable land, are weighing heavily on conventional agriculture. The related search for alternative food systems led to innovative ideas concerning urban food systems (UFS) (De Zeeuw and Drechsel, 2015), especially in megacities. One such major innovation related to the UFS is Vertical Farming (Besthorn, 2013; Despommier, 2009; Tornaghi, 2017). We define Vertical Farming as "cultivating vegetables vertically by new agricultural methods, which combines the design of building and farm all together in a high-rise building inside the cities" (Al-Chalabi, 2015; Kalantari et al., 2017). Vertical Farming is acknowledged in Japan, manifest in metropoles such as New York City, with rapid expansion in Europe (Butturini and Marcelis, 2020), and in Canada, the latter driven by legalization of cannabis (Kubota, 2020).

New VFs are incipient worldwide, with substantial popular media-coverage, dedicated technological innovations, rising amounts of tenders and substantial (venture) capital investments, but business frameworks remain vague. Research on VFs is focused on technical, environmental, and social aspects, with merely a few studies pertaining to the business dimension of VFs (Banerjee and Adenaeuer, 2014).

\section{Significance of this study}

What is already known on this subject?

- Research on Vertical Farming is focused on technical and environmental aspects, presented as lab or scenarios studies, and unique cases. One finds very little systematic knowledge regarding the prominent items in establishing commercially viable Vertical Farms.

What are the new findings?

- No specific placement ((peri-)urban or rural; climate and altitude conditions) offers a simple net positive result. A real concern is the need for food quality management and properly trained employees, to assure product quality and system efficiency. At firm level zoning issues create a real legal concern. Expectations are very diverse regarding the complexity of the endeavours, the dominant design, the high energy needs, product variety, and return on investments.

What is the expected impact on horticulture?

- The listing of prime items in the derived Vertical Farm Business Framework provides a shortlist of items to focus on in the commercial development of Vertical Farms.

Capital investments seem to make sense given the potential benefits of VFs, such as shorter supply chain, lower environmental impact, and relieving local food stress (Martin and Molin, 2019). However, the very diverse developments with potential for major innovations, misfit between location and demand, and shortage of skilled workers make the high investments risky, and funders hesitant (Michael, 2017). Due to its newness, the huge variety in VF-formats (Kozai, 2018), and the commercial sensitivity of data, there is still little to no public information regarding feasible business formats, investments, operational costs (and benefits), and profit potential (Shao et al., 2016). Therefore, this paper develops a conceptual business framework of the $\mathrm{VF}$, with the aim to raise our understanding of the major, generic items of VFs as a commercial endeavour. The study claims that the creation of a vertical farm business framework helps to get an overview of factors to be prioritized in the development of VFs.

The paper essentially answers two questions. The first research question is on what literature has to say about the organization, governance cooperation, and enabling environment constructs of a Vertical Farm Business Framework (VFBF). This will be answered by reviewing relevant literature and will conclude with a categorized shortlist of items 
and specific items in a VFBF. The second research question is what of the VFBF can be validated by those involved in the business of Vertical Farming. Due to the early commercialization stage that Vertical Farming is in, an exploratory study with dedicated, semi-structured interviews is the suited approach. This research is not intended and cannot in this early stage decipher if Vertical Farming is a viable business sui generis; instead it is focused on unveiling the items of key prominence for the Vertical Farming industry.

\section{Vertical Farm Business Framework}

Vertical Farming has emerged on different continents because of different causes. Important problems for agriculture is the scarcity of useable land for crop production in Japan, next to the estimated world population of 9.3 billion people in 2050, climate change, water shortage, and other factors (Kozai and Niu, 2020). Problems were leveraged by the lack of trust in open field food systems, after repeated scandals, environmental issues, and disasters (e.g., Fukushima). Parallel, in various Asian countries, many of them dependent on imported food supplies, personal wealth is rising, allowing for a premium priced market segment of fully conditioned plant factory-produce. Governments recognize the problems and potentials, and start supporting VF, for example by technology hubs in support of the VF-industry. The United States of America is mainly supplied long-distance by Californian or Mexican food produce. However, these long-distance shipments, widespread use of fertilizers and pesticides, making many freshwater sources unusable (Despommier, 2009), eight years of drought in California, and different levels of food qualities, with related pricing practices, prepared citizens for supporting new food formats. VF initiatives benefitted from the visionary views of professor Despommier on organic urban agriculture, and venture capital in search of speculative returns. In Europe, food systems are finegrained, advanced, and food quality is rather high and homogeneous, causing highly competitive prices. This leaves little room for premium prices for high quality, reliable foodstuff. Here social reasons of job creation, food education, and community support, drive initiatives in urban agriculture (Mougeot, 2000; Sanyé Mengual and Oliver i Solà, 2015; Specht et al., 2019). Such continentally different drivers of VF are seldom mentioned but impact expected VF-formats and decision-making. This, and the expected relative ease of access to data points, caused the researchers to restrict data gathering to Europe and the North American continent, starting with an inventory on the main items.

The literature-based VF business framework (VFBF) has been grouped under three broad constructs, each holding specific items, namely the organization (e.g., technology and innovation, geographic location, and product attributes), governance cooperation (e.g., position in the food chain and partnerships), and the enabling environment (social aspects, government support, legal aspects, training and education) (Griffiths and Zammuto, 2005; Waddell, 2016). The triad is foremost based on the typology of the vertical farm association (AVF, 2017). The construct Organization relates to a firm-centric description of the Vertical Farm project, relating to resources, core competencies, location, the product attributes, and other operational aspects of the company. The construct governance cooperation involves actors in the chain, business arrangements, the value chain, etc. The construct enabling environment, refers to the wider societal environment an organisation is active in (Table 1).

The first construct in our original VFBF-framework is Or- ganization. It relates to strategic decision making in terms of how and where the company will create what product, with the consideration of how advanced and innovative technology systems will be. Regarding technology and innovation, availability of technologies for VFs has increased and created more advanced applications, from automation to computer-assisted tools used for production, management, quality, and scientific data. Default technological systems are nutrient delivery systems, water management systems, light and power systems, plant cultivation systems, and environment control systems (Kozai and Niu, 2020; Zeidler et al., 2013). In more advanced horticultural regions, many available systems can be tailored to VF.

Commercial VFs can be split up in three business model categories (Brin, 2016): (1) Turn-key farm solutions and services; (2) Sales of vegetables and fish; and (3) Sales of systems. Turn-key solutions refer both to engineering, and to procurement and construction services, which encompasses solutions for construction designs, installations, maintenance, and VF-management. Turn-key farm solutions and services act in two manners, through business-to-business (B2B), and business-to-consumer (B2C) transactions. When looking for B2B, one provides a package of commercial systems and small farm systems. Turn-key B2C solutions refer to home appliances. The second type of business model, Sales of vegetables and fish, focus on selling end products to retailers or even the consumer. Selling directly to the consumer can be done through e-commerce or the business's own selling point. Regarding the category Sales of vegetables and fish, B2B orients at retail and wholesale, while B2C involves own selling points, home delivery, and e-commerce. Third and final, the business model Sales of systems typically uses VFs to demonstrate, promote, sell their concepts, and/ or alternatively offer facilities for research (Brin, 2016). Next, the geographic location issues regard a VF. Additionally, the product attributes/characteristics are also key for VF, here classified under Organization. Vegetables and herbs from a VF are supposed to claim higher prices per kilogram due to the (still) high production costs (Birkby, 2016). Product characteristics relate not only to freshness, and nutritional value, but also to traceability, GM-free or not, and pesticideand herbicide-usage. Characteristics are important in terms of product acceptance, product placement, and product marketing, to realise a suited willingness to buy.

The second construct of the framework is Governance \& cooperation, involving the position choice in the food chain, and supportive partnerships for related activities (Nieto and Santamaría, 2010; Takeshima and Joshi, 2019). Common actors in conventional food chains are input providers, primary food producers, food processors, distributors, wholesalers, retailers, and the consumer. In the case of a VF, the number of actors varies depending on the preferred positioning in the chain, the selected level of chain integration. A VF may choose to process and package the products themselves, and facilitate the logistics to traders, or distribution centers, or final consumers (Sharma and Patil, 2018). This may result in a shorter chain, with fewer chain actors, and a related (higher) share for the VF of the consumer payments for the final product. A fully integrated chain generates more information, lowers the so-called transactions costs, and allows for stricter (quality) control and VF-dedicated investments within the supply chain, which increases predictability and steering potential (Kneafsey et al., 2013; Loertscher and Riordan, 2019). Over time disadvantages of such so-called vertical integration may come to dominate the advantages (Per- 
ry, 1989). One should think of high investments for dedicated equipment and constructions, and generic supply chain activities, the required very different specialized employees, underutilization of potential partners' knowledge development, and the lowering of one's flexibility while markets still evolve. Partnerships may relate specialized technology or turn-key system providers, consultants, private and public research centers, useful to solve both daily operational problems, and longer-term issues such as energy demand, and improving the overall efficiency of the production system (Kozai et al., 2020).

The third construct of the framework is the Enabling environment. Within this construct, it is claimed that the social aspects, governmental support, and legal aspects are key to vertical farms, to enable the specific setting that a vertical farm needs (Bruce, 2019). Regarding social aspects, community involvement comes in two forms, namely the people active in the VF, and those that may impact the appreciation of the VF-concept in society and politics (Thomaier et al., 2015). Building VFs creates economic activities and job opportunities for local citizens, to the benefit of the overall welfare of a community. However, when thinking about social issues regarding VFs, note that interviewees, when asked about hydroponics, mentioned VFs being 'not natural', and the use of 'chemicals,' indicating an overall negative perception (Al-Chalabi, 2015; Kalantari et al., 2017). Some Japanese elementary schools familiarize children with the VF-concept, by including VF in teaching on food provision (Brin, 2016). Creating a transparent company image towards consumers can incite the willingness to pay a premium for the green image of local, healthy food. Governmental support varies a lot, but is critical, as subsidies and spatial policies are seldom suited to VFs. Local and federal authorities find it hard to assess the activity, and thus to support or hinder, while established practices hinder societal recognition and food sector integration. Not to be underestimated is the legal aspect, especially the lack of a constructional code that fits VFs: is it industrial or agricultural; allow VF in retrofitted or only dedicated buildings, and what are the suited (food) safety, zoning, building and HR requirements, that might restrict farming (Angotti, 2015; Mukherji and Morales, 2010)? The legal aspect has increased delays and investment costs such that initiatives have been cancelled. It remains unclear if the regulatory issues should be settled on regional, local or even a case-by-case basis. Simultaneously, there is a need for international regulations to raise collaborations, economies and speed within the entire VF industry (Brin, 2016; Slingerland et al., 2006). Table 1 summarizes the Vertical Farm Business Framework, including the specific items, and operationalizations.

\section{Methodology}

Because VF management is still hardly studied, an exploratory research, starting with a literature study, was considered suited. Exploratory research suits research areas where little is systematically known, to investigate the prominence of (sub-)items, and conceptual links (Kumar, 2014). For exploratory research, open-ended questions are recommended when the sets of suited answers are not completely known (Züll, 2016). They encourage the respondent to answer and argue by their own words and terms (Kumar, 2014). Non-probability, expert sampling is the most suited method to build a research population in qualitative research $(\mathrm{Ku}-$ mar, 2019). The experts in this research are the VF growers and VF industry participants. The commercial VF industry is relatively new, but sufficiently mature enough to interview business owners and others, who are experienced in agriculture, agrotechnology, and agribusiness. An online survey was developed and pretested but concluded to be long and too complex. In 2019, a shorter, upfront survey was sent out to 40 experts, and a personal network in the VF industry has been developed to realise more interviews.

The research population is mainly located in Europe (EU) and North America (US or CA). Initially, dedicated search terms, such as "Vertical farms", "Vertical farms USA", "Plant factory", "Indoor farm", "Urban farm", and "CEA", that is "controlled environment agriculture", were used to find suited companies. We arrived at a list of 150 companies. The second phase comprised of connecting and committing persons to realise their willingness to be interviewed. This was realised by attending VF conferences GreenTech conference in Amsterdam, and the Indoor Ag-Con in Las Vegas, in addition to collaboration with the Farm Tec Society. LinkedIn was used to connect to these previously met persons and send them an introductory mail. Most interviews were over phone and occasionally through Skype or Zoom. The interviews were recorded, and notes were taken during the interview. The interviewed records were transcribed and sent to the participant for permission and affirmation of their given answers.

We had to stop interviewing at a total of 25 participants $(N=25)$, somewhat below the goal of 30 (See Appendix 2: Map of interviewees). 13 interviewees were from the USA, 1 (VF-manager) from Canada and 11 from Europe. 13 interviewees manage a vertical/indoor farm, and 12 were industry participants, especially in consulting, researching VF systems, researching the industry, investors, or operational support and service providers. Although most interviewees have less than 5 years of direct VF-experience, some had over 20 years of relevant experience. One VF-manager had experienced bankruptcy. Interviews ranged from 15 till 60 minutes each and were conducted over a time period of three months. Participants were promised not to disclose names, to make them more willing to answer frankly.

So, for this exploratory research, a diverse group of 25 participants, nicely spread out over Europe and North America, were interviewed to discuss and validate the various aspects of the framework. The VFBF allowed us to develop an interview guideline, with items used as a topic list for the interviews. The guideline provided generic questions for each item, and interviews were tailored to suit the experience and expertise of the interviewee. The original interview guideline comprised of 14 questions, such as: What is the importance of technological innovation for your VF? Based on and after four interviews, the topic of vocational training has been added, together with a question regarding the prospects of the industry within the next 5 years. All interviews were transcribed, and analysed using self-determined codes with MAXQDA, to identify the prominence of the VFBF aspects and to better understand the participants' answers. (Kumar, 2014). MAXQDA helps to classify the data with coding and identifying main themes, where the frequency of certain themes/codes are supposed to indicate prevalence (Kumar, 2019).

In line with standards in qualitative data research we had a first-order analysis of the data (open and axial coding) and second-order analyses (relate to theoretical concepts) (Gioia et al., 2013). The round of open coding, using MAXQDA, resulted in a large amount of codes (124), incl. frequent texts sections fitting several codes. The researchers identified similar code names to subcategorize and merge codes (e.g., 
the "direct to consumer", "close to consumer", "consumer distance", and "B2C" were labelled B2C). By doing this, the amount of codes was decreased to 44 codes (see Appendix 1: Code structure). In the round of axial coding, codes were grouped according to operational items of the research. This resulted in eight items and two additional themes, namely education \& training, and prospects. In the second-order analysis, the codes and their related text segments were grouped per item to search and suggest concepts and relations (Gioia et al., 2013). Using computerized analysis supports the systematic approach for all transcripts, bringing us the final coding structure. The data did not provide clear indications to subgroup the data along characteristics.

\section{Results and discussion}

The analysis will present the interpreted information as derived from the qualitative data research, organized by the three constructs as presented in the vertical farm business framework. The construct Organization is the firm centric construct that includes technology \& innovation, geographic location, and product attributes. In terms of technology \& innovation, the economic aspect (cost, feasibility, economy of scale, and profitability) is still negative for vertical farms (Angotti, 2015; Banerjee and Adenaeuer, 2014; Zeidler et al., 2017), but having an optimized production process is equally important: However, the industry needs more commercial successes, but I'm not sure if it's going to be on large or medium business scale (interview quote). It is not necessary to have high tech systems with robotics to be able to produce a consistently high-quality product. The selection of a geographic location for the VF has a large impact on the VF's strategy and plays an overall role in the success of the farm. Within three miles we do have high end restaurants. It is a poor area but further down it is totally different (interview quote). Harsh climates or places with a lack of conventional agriculture can be suitable for VFs, in addition to locations with abundant renewable energy. Being in the urban core of a city can be limiting compared to being in peri-urban or more rural areas: Urban areas have great potential in terms of social value and niche business models. Meanwhile, peri-urban or rural areas have greater chances of reaching an economy of scale and partnering with larger corporations. Reviewing all items in the decision-making, vertical farms can be found in all three areas, contrary to initial expectations on VFs (Specht et al., 2014). Most of the interviewed VFs grow a product in the range of aromatic herbs, leafy greens, microgreens, or salads. The stated product attributes (e.g., local, pesticide free, etc.) of VFs are often similar. 10 out of 25 participants mentioned the consistent high quality as one of the most important aspect of the business. These so-called high-end products have a high price, recognized in interviews as contradictory with the vision of "feeding the world". The rejoinder we derive from the interviews is that Vertical Farming is in a development phase; it is expected that VFs will grow other crops later.

The second construct, Governance cooperation, is the construct of working with various partners and actors in the food value chain. The position in the food chain is largely influenced by the geographic location but determines the business strategy of the VF. Initially, Business-to-consumer vertical farming was primarily dominant in the industry. However, there are a lot of opportunities targeting different buyers. Investments in VF-vending models in grocery stores, is considered practical nor feasible, but it helps vertical farming in advancing consumer acceptance of the technology. Working on a larger scale can support the potential relationships with
TABLE 1. Overview of constructs, selected items and operationalizations.

\begin{tabular}{|c|c|}
\hline \multicolumn{2}{|c|}{ Vertical Farm Business Framework } \\
\hline Items & Operationalizations \\
\hline \multicolumn{2}{|r|}{ The organisation } \\
\hline Technological innovation & $\begin{array}{l}\text { VF systems/ data support/weather } \\
\text { exposure/sustainability }\end{array}$ \\
\hline Geographical location & Geo-characteristics/climate/urban-rural \\
\hline Product characteristics & Freshness/nutritional value/GM/ pesticides \\
\hline \multicolumn{2}{|c|}{ Governance cooperation } \\
\hline Position in food chain & $\begin{array}{l}\text { B2B-B2C/segments till end user/ } \\
\text { stakeholders }\end{array}$ \\
\hline Partnerships & Technological/operational/capital \\
\hline \multicolumn{2}{|c|}{ Enabling environment } \\
\hline Social aspects & Community involvement/social investment \\
\hline Governmental support & Subsidies/local recognition/industry support \\
\hline Legal aspects & Legal issues/food law/constructional \\
\hline
\end{tabular}

large food manufacturers and retail distribution centres. The existing infrastructure can support the VF and still have major supply chain cuts as the VF can be built in the area of its potential buyers. We are on the campus of a very large distribution centre. We use one of their buildings, so our produce just goes across the street (interview quote). The variable key partnerships have an important role of filling in the specific knowledge or expertise gap the VFs might have. In this phase collaboration is important because it is a new industry, and a lot still must be developed (interview quote). A second type of possible partnerships is with local organizations to better understand the local character of certain areas and its customers, such as do we need farming expertise, do we need technological support, what are the local organizations?

The third construct, Enabling environment, is the supporting construct of the VF business and industry. The social aspect was found to be important to some, and not so much to others. The social/people-oriented strategy is more likely for (peri-)urban areas as the farm is located in a living space. There is a trade-off between being truly socially valuable for a community and having an optimized VF system on a reasonable economy of scale. However, community involvement can be beneficial as it can lead to consumer acceptance and connecting with local organizations. I think for the larger ones, it is more a marketing aspect, but for the smaller ones, it is more mission-related (interview quote). Having government support shouldn't be a main concern for a VF as it is something that can grow over time as the industry market share increases. All VFs agreed on the lack of recognition and support from their government. There is no clear pathway for when you want to start a vertical farm (interview quote). There are more opportunities to have local municipality support, especially when the farm is social-oriented. The two major concerns for the legal aspects are food safety, zoning, and building regulations: We are growing food where there was not food growing before. So, food safety questions arise as well. Also, the definition of vertical farming is very vague and unclear (interview quote).

The fourth aspect is Education \& training, that provides the industry with vocationally trained people. Both in farming skills and academic knowledge-based plant science and agronomy. No matter the model of VFs, all interviewees mentioned a high need for properly trained and skilled employees (Michael, 2017). There is a lack of growers in the industry: There 
TABLE 2. Concluded items Vertical Farm Business Model (bold items are validated by the interviews).

\begin{tabular}{lll}
\hline & \multicolumn{1}{c}{ Vertical Farm Business Framework } & \\
\hline Organisation & Governance cooperation & Enabling environment \\
\hline Technology \& innovation: & Position in the food chain: & Social aspects: \\
- Economics (scale economies, & Business-2-Business & - Community involvement \\
profitability, feasibility, costs) & - Distribution centres & - Consumer recognition \& acceptance \\
- Optimized systems & - Food manufacturers & - Local partners \\
- Automation and labour & - Pharmaceutical industry & - Social value \\
- High tech & & \\
- Renewable energy & Business-2-Consumers & Governmental support: \\
& - Consumer & - Local municipality \\
Geographical location: & - Retail & - Industry recognition \\
- Strategic location & & - Federal support \\
- Harsh climate & & \\
- Agriculture & Key partnerships: & Legal aspects: \\
- Availability of input resources & - Agronomy experts & - Food regulations \\
& - Knowledge gap & - Zoning and building regulations \\
Product attributes: & - Local partners & \\
- Consistent high-quality & & Education \& Training: \\
- Premium product & & - Vocationally trained employees \\
- Nutritious and tasty & & - Universities \\
- Local, fresh, pesticide-free & & Adapted curriculum \\
& & Research \& development \\
\hline
\end{tabular}

is a lack of training and there are no schools and programs. It is not about the low wage labour but [about] people who understand the systems, it is not like field farming (interview quote). Technology driven vertical farming may be a great way to attract younger farmers and students to agriculture.

Additionally, the interviews informed us somewhat about perceptions of prospects. It is important to realize that VFs still realise a very small market share, but show high differentiation, and are innovation oriented. For the coming five years the opinions of the research group are very diverse. Four industry participants go for greenhouses and the hybrid models. Various interviewees are still wondering how the larger VFs with high investments, are going to gain back their investment with a reasonable return on investments. The story is easy to sell, I don't understand why so many people are fooled, and everybody who is already in the business for many years don't truly believe in it, they don't believe it can feed the world (interview quote). Six industry participants have little belief in VFs, if they continue to be more expensive, consume high amount of energy, and lack product variety. Europe is seen as the most difficult area for commercial vertical farms because of the efficiency and quality of its current food system, where at low-end or high-end, you'd likely find the same produce, at relatively low prices. In contrast, several US participants and one EU industry participant are positive about Vertical Farming potentials and emphasized their long-term goals. Knowledge is now the value behind it and not the business case. Of course, the ultimate goal is to make money at some point. But look at Facebook, it took them a very long time to make money (interview quote). The main improvements are expected in efficiency, new technologies, more robotics, and automations. Automation was mentioned by 16 of 25 participants, especially in terms of finding more applications in various production steps. Five industry participants mentioned the rise of the cannabis industry and its high potential. Along the same line of reasoning, the potential of Vertical Farming for pharmaceuticals was also mentioned. No generic learning regards prospects for VFs can be distilled from this specific research project.
Table 2 presents the finalized Vertical Farm Business Framework, with the three constructs and their specific items. Vertical Farming has many items that come into play in the industry, especially in this developmental stage of industry life cycle. The prominent items elicited from the interviews and referred to by the participants with higher prominence are marked in bold.

\section{Conclusion}

To wrap up, over the past 10 years the drive for new agriculture methods that can alleviate climate change brought us Vertical Farming, a promising and innovative format of advanced farming, albeit building on technological innovations already developed before the turn of the century. Nevertheless, establishing a commercially viable Vertical Farm remains a complex matter that involves many items and real strategic decision making.

Regarding the construct Organization, the participants posit it is only a matter of time that improved technologies in terms of lighting, HVAC, and automation are developed, in addition to a change in the energy equation that depends on the evolution of green energy. These changes can and should drastically decrease the overall costs of Vertical Farms. The variety of leafy greens as dominant cultivar of choice is considered reasonable for the first phase of the industry life cycle. The location influence of a VF comes from its placement in an urban, peri-urban, or rural area, and the climate and altitude conditions. However, no specific placement offers a simple net positive or negative result.

When it comes to the construct Governance cooperation, the current most common position in the food chain is selling to the consumer directly or via grocery stores. There is still a strong belief in the potential and feasibility of VF integration, but new higher value products must arise (e.g., stevia, marijuana). As the industry is still developing, good partnerships are fitting, especially with distribution centres and specific food sectors, to further integrate at larger scale in the food chain. 
Regarding the construct Enabling environment, the results show that more evidence is needed to show the social value of Vertical Farms in cities. Despite the large time investment, legal issues were not found to be a major concern, apart from zoning issues. As for all food businesses, the need for food quality management and expertise is evident. Government support is deemed important for the VF industry, but not always for individual local farms. It is predicted government support will increase with rising market shares and public acknowledgement of VF produce. An emergent but prominent theme became the need for properly trained employees, especially in the area of plant science and agronomy. It is a key success factor to have a knowledgeable team that can mitigate growing issues to assure product quality and system efficiency. The technology-driven VFs attract a newer and younger generation of future farmers.

The developed framework in this research presents the major items of the Vertical Farming as a commercial endeavour, and thereby specifies the more important items when discussing the diverse types of Vertical Farms from a business-perspective. Analysing and reviewing Vertical Farms in the sense of solving global food security is off scope. If the energy equation is not solved, economies of scale will not be reached, calorie-dense products will not be grown, resulting in a minor contribution to the food system.

This research is exploratory and qualitative, making it difficult to draw generalizations. In this new industry, many businesses are still in the research and development phase, and the variety is large as is the dynamics between North American and European markets. Furthermore, participants indicated that Vertical Farming may have better adaptation in Asia, especially due to a lack of trust in their food systems. Due to lack of accessibility to enough interviewees we did not elaborate such other regions in this study.

\section{References}

Al-Chalabi, M. (2015). Vertical farming: Skyscraper sustainability? Sustainable Cities and Soc. 18, 74-77. https://doi.org/10.1016/j. scs.2015.06.003.

Angotti, T. (2015). Urban agriculture: long-term strategy or impossible dream? Lessons from prospect farm in Brooklyn, New York. Public Health 129(4), 336-341. https://doi.org/10.1016/j. puhe.2014.12.008.

AVF (2017). Urban Agriculture Integration Typology. https:// vertical-farming.net/vertical-farming/integration-typology/.

Banerjee, C., and Adenaeuer, L. (2014). Up, up and away! The economics of vertical farming. J. Agric. Studies 2(1), 40-60. https:// doi.org/10.5296/jas.v2i1.4526.

Besthorn, F.H. (2013). Vertical farming: Social work and sustainable urban agriculture in an age of global food crises. Austral. Soc. Work 66(2), 187-203. https://doi.org/10.1080/0312407X.2012.716448.

Birkby, J. (2016). Vertical Farming. ATTRA Sustainable Agriculture (National Agricultural Information Service), January.

Brin, H. (2016). The state of vertical farming. https://verticalfarming.net/whitepapers/.

Bruce, K. (2019). Enabling environment for PPPs in agricultural extension projects: Policy imperatives for impact. J. Rural Studies 70, 87-95. https://doi.org/10.1016/j.jrurstud.2019.07.005.

Butturini, M., and Marcelis, L.F.M. (2020). Vertical Farming in Europe: Present status and outlook. In Plant Factory, $2^{\text {nd }}$ edn., T. Kozai, G. Niu, and M. Takagaki, eds. (Elsevier), p. 77-91. https://doi.org/10.1016/ B978-0-12-816691-8.00004-2.
De Zeeuw, H., and Drechsel, P. (2015). Cities and Agriculture: Developing Resilient Urban Food Systems. (Routledge). https://doi. org/10.4324/9781315716312.

Despommier, D. (2009). The rise of vertical farms. Sci. Amer. 301(5), 80-87. https://doi.org/10.1038/scientificamerican1109-80.

Gioia, D.A., Corley, K.G., and Hamilton, A.L. (2013). Seeking qualitative rigor in inductive research: Notes on the Gioia methodology. Organiz. Res. Meth. 16(1), 15-31. https://doi. org/10.1177/1094428112452151.

Griffiths, A., and Zammuto, R.F. (2005). Institutional governance systems and variations in national competitive advantage: An integrative framework. Acad. Manag. Rev. 30(4), 823-842. https:// doi.org/10.5465/amr.2005.18378880.

Kalantari, F., Mohd Tahir, O., Mahmoudi Lahijani, A., and Kalantari, S. (2017). A review of Vertical Farming Technology: A guide for implementation of building integrated agriculture in cities. Paper presented at: Advanced Engineering Forum. https://doi. org/10.4028/www.scientific.net/AEF.24.76.

Kneafsey, M., Venn, L., Schmutz, U., Balázs, B., Trenchard, L., EydenWood, T., and Blackett, M. (2013). Short food supply chains and local food systems in the EU. A state of play of their socio-economic characteristics. JRC Scientific and Policy Reports (Luxembourg: Publications Office of the EU).

Kozai, T. (2018). Smart Plant Factory: The Next Generation Indoor Vertical Farms (Singapore: Springer Nature). https://doi. org/10.1007/978-981-13-1065-2.

Kozai, T., and Niu, G. (2020). Role of the plant factory with artificial lighting (PFAL) in urban areas. In Plant Factory, $2^{\text {nd }}$ edn., T. Kozai, G. Niu, and M. Takagaki, eds. (Elsevier), p. 7-34. https://doi. org/10.1016/B978-0-12-816691-8.00002-9.

Kozai, T., Niu, G., and Takagaki, M. (2020). Plant Factory: An Indoor Vertical Farming System for Efficient Quality Food Production, $2^{\text {nd }}$ edn. (London, UK: Academic Press).

Kubota, C. (2020). North America. Plant Factory, $2^{\text {nd }}$ edn., T. Kozai, G. Niu, and M. Takagaki, eds. (Elsevier), p. 69-73. https://doi. org/10.1016/B978-0-12-816691-8.00002-9.

Kumar, R. (2014). Research Methodology (Sage Publications Ltd.).

Kumar, R. (2019). Research Methodology: A Step-by-step Guide for Beginners (Sage Publications Ltd.)

Loertscher, S., and Riordan, M.H. (2019). Make and buy: Outsourcing, vertical integration, and cost reduction. Am. Econ. J.: Microeconomics 11(1), 105-123. https://doi.org/10.1257/mic.20160347.

Martin, M., and Molin, E. (2019). Exploring the Environmental Performance of Urban Symbiosis for Vertical Hydroponic Farming. Sustainability 11(23), 6724. https://doi.org/10.3390/su11236724.

Michael, C. (2017). 9 reasons why vertical farms fail. https:// university.upstartfarmers.com/blog/9-reasons-why-vertical-farmsfail.

Mougeot, L.J. (2000). Urban agriculture: Definition, presence, potentials and risks, and policy challenges. Cities Feeding People Series, Rep. 31 (Ottawa, Canada: IDRC).

Mukherji, N., and Morales, A. (2010). Zoning for urban agriculture. Zoning Practice 3(10), 2-7.

Nieto, M.J., and Santamaría, L. (2010). Technological collaboration: Bridging the innovation gap between small and large firms. J. Small Bus. Manag. 48(1), 44-69. https://doi.org/10.1111/j.1540627X.2009.00286.X.

Perry, M.K. (1989). Vertical integration: determinants and effects. Handbook of Industrial Organization 1, 183-255. https://doi org/10.1016/S1573-448X(89)01007-1. 
Sanyé Mengual, E., and Oliver i Solà, J. (2015). Sustainability Assessment of Urban Rooftop Farming Using an Interdisciplinary Approach (Barcelona: Universitat Autònoma de Barcelona).

Shao, Y., Heath, T., and Zhu, Y. (2016). Developing an economic estimation system for vertical farms. Int. J. Agric. Environm. Inform. Syst. 7(2). https://doi.org/10.4018/IJAEIS.2016040102.

Sharma, M., and Patil, C. (2018). Recent trends and advancements in agricultural research: An overview. J. Pharmacogn. Phytochem. 7(2), 1906-1910.

Slingerland, M., Ruben, R., Nijhof, H., and Zuurbier, P. (2006). Food chains and network for development. In Agro-Food Chains and Networks for Development, M. Slingerland, R. Ruben, and H. Nijhof, eds. (Dordrecht, The Netherlands: Springer), p. 219-231.

Specht, K., Siebert, R., Hartmann, I., Freisinger, U.B., Sawicka, M., Werner, A., and Dierich, A. (2014). Urban agriculture of the future: An overview of sustainability aspects of food production in and on buildings. Agric. Human Val. 31(1), 33-51. https://doi.org/10.1007/ s10460-013-9448-4.

Specht, K., Zoll, F., Schümann, H., Bela, J., Kachel, J., and Robischon, M. (2019). How will we eat and produce in the cities of the future? From edible insects to Vertical Farming - A study on the perception and acceptability of new approaches. Sustainability 11(16), 4315. https://doi.org/10.3390/su11164315.

Takeshima, H., and Joshi, P.K. (2019). Protected agriculture, precision agriculture, and vertical farming: Brief reviews of issues in the literature focusing on the developing region in Asia (Vol. 1814) (Int. Food Policy Res. Inst.).

Thomaier, S., Specht, K., Henckel, D., Dierich, A., Siebert, R., Freisinger, U.B., and Sawicka, M. (2015). Farming in and on urban buildings: Present practice and specific novelties of Zero-Acreage Farming (ZFarming). Renewable Agric. Food Syst. 30(1), 43-54. https://doi. org/10.1017/S1742170514000143.

Tornaghi, C. (2017). Urban agriculture in the food-disabling city: (Re) defining urban food justice, reimagining a politics of empowerment. Antipode 49(3), 781-801. https://doi.org/10.1111/anti.12291.

Waddell, S. (2016). Societal change systems: A framework to address wicked problems. J. Appl. Behav. Sci. 52(4), 422-449. https://doi. org/10.1177/0021886316666374.

Zeidler, C., Schubert, D., and Vrakking, V. (2013). Feasibility study: Vertical Farm EDEN (DLR Institute of Space Systems).

Zeidler, C., Schubert, D., and Vrakking, V. (2017). Vertical Farm 2.0: Designing an Economically Feasible Vertical Farm A Combined European Endeavor for Sustainable Urban Agriculture (Association for Vertical Farming). https://www.researchgate.net/ publication/321427717.

Züll, C. (2016). Open-Ended Questions. GESIS Survey Guidelines. (Mannheim, Germany: GESIS - Leibniz Institute for the Social Sciences),

https://doi.org/10.15465/gesis-sg_en_0a02.https:// eur06.safelinks. protection.outlook.com/ ?url=https $\% 3 \mathrm{~A} \% 2 \mathrm{~F} \% 2 \mathrm{Fwww} . g e s i s . o r g \% 2 \mathrm{~F}$ fileadmin\%2Fupload\%2FSDMwiki\%2FZuell_OpenEnded_Questions. pdf\&amp;data =02\%7C01\%7C\%7Cd1330386c97c4edd6d9008d7fbe 14b50\%7C84df9e7fe9f640afb435aaaaaaaaaaaа7C1\%7C0\%7C637 254817667060095\&amp;sdata=4iHTHBKSV2PUDAWMj8aykZbeBd 1VMwLcS52GdMoHxcA\%3D\&amp;reserved=0.
Received: May 4, 2020

Accepted: Aug. 7, 2020

Address of authors:

Simon Allegaert, Emiel F.M. Wubben* and Geoffrey Hagelaar Business Management and Organisation, Wageningen University, Hollandseweg 1, 6706 KN Wageningen, The Netherlands

* Corresponding author; E-mail: emiel.wubben@wur.nl Tel.: +31 (0)317-484428 
APPENDiX 1. Code structure.

\begin{tabular}{|c|c|c|}
\hline Items (axial coding) & Indicators (open coding) & Text example from interviews \\
\hline & & The organization \\
\hline \multirow[t]{7}{*}{$\begin{array}{l}\text { Technology and } \\
\text { innovation }\end{array}$} & Automation & $\begin{array}{l}\text { We will need to figure out how to decrease the labor and this will be possible } \\
\text { because of robotics and more automation. }\end{array}$ \\
\hline & Economy of scale & $\begin{array}{l}\text { However, the industry needs more commercial successes, but l'm not sure if it's } \\
\text { going to be on large or medium business scale. }\end{array}$ \\
\hline & Track record/Proof & $\begin{array}{l}\text { But there must be more proof of how good the produce is of vertical farming. } \\
\text { I still wonder how they are going to get there investments back. }\end{array}$ \\
\hline & Profitability & $\begin{array}{l}\text { If your analysis is bad and you have no marks or no profit, then it is not going to } \\
\text { work, and you are doing something that is wrong. }\end{array}$ \\
\hline & High tech & $\begin{array}{l}\text { I think they are working to complicated, too high tech and are missing the point. } \\
\text { They are being too difficult and may be using too many algorithms. }\end{array}$ \\
\hline & Cost & It is not going to work anywhere soon unless electricity gets cheaper or free. \\
\hline & Complications & $\begin{array}{l}\text { Combining the wrong components in building typology and using the wrong } \\
\text { potentials in energy consumption result in a negative situation. }\end{array}$ \\
\hline \multirow[t]{5}{*}{ Geographic location } & Food supply & $\begin{array}{l}\text { Basically, in most of the western countries the food supply is working perfectly, } \\
\text { low prices and good produce. }\end{array}$ \\
\hline & Sub urban & $\begin{array}{l}\text { We are in the side boarder of this city, } 9,000 \mathrm{~m}^{2} 14,000 \text { bags per day, and } \\
\text { everything goes to the city. The ground wasn't that expensive. }\end{array}$ \\
\hline & Climate & $\begin{array}{l}\text { Especially locations with harsh climates, which makes it difficult for conventional } \\
\text { agriculture to grow food. }\end{array}$ \\
\hline & Demographic & $\begin{array}{l}\text { In this way you have a certain market. I also saw that in Japan, and so you can } \\
\text { reduce your distribution risk and you can grow for a specific demographic. }\end{array}$ \\
\hline & Urban core & $\begin{array}{l}\text { But like you see in New York and Chicago, having a greenhouse on a roof can } \\
\text { also be a perfect solution for urban farming. }\end{array}$ \\
\hline \multirow[t]{3}{*}{ Product } & Branding & $\begin{array}{l}\text { It is private label. It has to be. It is hard to bring your own brand, there was no } \\
\text { room for. However, we would love to. }\end{array}$ \\
\hline & Consistent quality & $\begin{array}{l}\text { This give you a certain stability and can bring you the focus on growing with } \\
\text { a consistent product quality for your market, even if you have a small-scale } \\
\text { farm. A problem with vertical farms is over-promising and underdelivering the } \\
\text { technology. So under-promising and overdelivering is a valuable key aspect. }\end{array}$ \\
\hline & Premium & $\begin{array}{l}\text { People are not going to eat indoor produce because it comes out of an indoor } \\
\text { farm, but just because it will taste better, and it will be cleaner and safer. }\end{array}$ \\
\hline \multicolumn{3}{|c|}{ Governance cooperation } \\
\hline \multirow[t]{5}{*}{$\begin{array}{l}\text { Position in the food } \\
\text { chain }\end{array}$} & Food manufactures & $\begin{array}{l}\text { I believe there is a lot of value in the B2B, the cooperation of a VF with the larger } \\
\text { food manufacturers. I know a few examples, but the names are confidential. } \\
\text { But yes, that's where the real opportunity is. }\end{array}$ \\
\hline & Retail & We have standing orders with a large grocery chain here. \\
\hline & Restaurants and public spaces & $\begin{array}{l}\text { Facebook, Google, schools are also good opportunities for vertical farms to } \\
\text { produce food for a large group of people locally. }\end{array}$ \\
\hline & Vending model & And the idea of small VFs on supermarkets doesn't look economically feasible. \\
\hline & Distribution model & $\begin{array}{l}\text { You have basically two models. Being next to the distribution center of a large } \\
\text { retailer or building a farm for a certain area with the aim of feeding that specific } \\
\text { area with a super local food chain. }\end{array}$ \\
\hline \multirow[t]{5}{*}{ Partnerships } & Trader/seller & $\begin{array}{l}\text { The trader, the client, is a crucial point, the others depends on the modal or what } \\
\text { you actually need? }\end{array}$ \\
\hline & Venture capitalist & $\begin{array}{l}\text { In this stage, money is really important, so my key partner is the other venture } \\
\text { capitalist. He is really good in finance, which is important in this stage. }\end{array}$ \\
\hline & Operational support and service & $\begin{array}{l}\text { You need to find the right partners for the installations and environment control } \\
\text { aspects, good seed suppliers, and if you don't have the knowledge to run farm } \\
\text { then you need a good partner for that as well. }\end{array}$ \\
\hline & Expert knowledge & $\begin{array}{l}\text { VFs need educational capacity and research capacity, so academics can help to } \\
\text { validate and figuring out. But of course, some tech providers are also important. }\end{array}$ \\
\hline & Local knowledge & $\begin{array}{l}\text { We are also connecting with all the resources in our regional, local area to make } \\
\text { them aware that we are transforming ourselves. }\end{array}$ \\
\hline
\end{tabular}




\begin{tabular}{|c|c|c|}
\hline \multicolumn{3}{|r|}{ Enabling environment } \\
\hline \multirow[t]{3}{*}{ Social aspects } & Community involvement & $\begin{array}{l}\text { Really important, it is one of the critical points of a vertical farm business. } \\
\text { You need to know the local community, you need to know what they want, what } \\
\text { they need. They also need to know what you are doing. You have to collaborate } \\
\text { to have that social aspect. }\end{array}$ \\
\hline & Consumer acceptance & $\begin{array}{l}\text { I'm not sure, because a lot of people already eat hydroponics, but they don't know. } \\
\text { Educating people about all the possibilities and opportunities of vertical farming } \\
\text { can be really helpful and cool to do. And l'm already talking with an organization } \\
\text { doing that now. }\end{array}$ \\
\hline & Social value & $\begin{array}{l}\text { We were looking to add value to the community and find a way to help people } \\
\text { with a disability by providing work. So, it was about creating a workspace that was } \\
\text { easy accessible for the community. }\end{array}$ \\
\hline \multirow[t]{4}{*}{ Governmental aspects } & Governmental support & $\begin{array}{l}\text { Yes, we do, the government is really open and receptive to urban farming, so we } \\
\text { have several levels of government support, from the government, municipality } \\
\text { and federal government. }\end{array}$ \\
\hline & Policies & There is a lack of policy. \\
\hline & Relationships & Yes, we need more support, I'm also talking with some politician. \\
\hline & Acknowledgements & $\begin{array}{l}\text { There is more need for recognition of the systems, as in recommendation of } \\
\text { vertical farms in cities. }\end{array}$ \\
\hline \multirow[t]{2}{*}{ Legal aspects } & Regulations & Food standards, local strict zoning rules, just the regular pathway is pretty strict. \\
\hline & Building and land & I don't really know, but I think city farms struggle with real estate. \\
\hline \multicolumn{3}{|r|}{ Undefined } \\
\hline \multirow[t]{7}{*}{ Other aspects } & Hybrid model & $\begin{array}{l}\text { The border between vertical farms and greenhouses will fade away. Large farmers } \\
\text { have come to us and asked for help with the lights. I see more an intermediate } \\
\text { form of an indoor farm and a greenhouse that is more efficient and proven. } \\
\text { When that happens, we will see much more of them. }\end{array}$ \\
\hline & Agricultural issues & $\begin{array}{l}\text { VFs profile themselves as food providers of the world, but they are making high- } \\
\text { end expensive products, which is a contradiction. }\end{array}$ \\
\hline & Market and industry & $\begin{array}{l}\text { The founders of the bigger vertical farmers are really big believers in this industry, } \\
\text { and they managed to set up something and get investments. However, they still } \\
\text { can fail or never be able to really compete. }\end{array}$ \\
\hline & Data/knowledge sharing & $\begin{array}{l}\text { It is normal in the early stages of any industry. Sharing service, data, infrastructure } \\
\text { will become greater than keeping every secret. Same happened in the software } \\
\text { industry. Over time they developed standards and open sourcing. I think in the } \\
\text { long term it will be beneficial for the VFs to work together but they need a center. }\end{array}$ \\
\hline & Asia/EU/USA & $\begin{array}{l}\text { People in China don't trust the regular vegetable; even the government can't } \\
\text { ensure the food safety. So obviously people have more willingness to pay } 5 \text { times } \\
\text { more for vegetables that are safe to eat. Also, China is getting more and more } \\
\text { rich people who can afford it. }\end{array}$ \\
\hline & The Netherlands & $\begin{array}{l}\text { You can visit in the Netherlands the commercial indoor farms. They all grow } \\
\text { their crops or flowers and market them, but they laugh with those vertical farms. } \\
\text { Because they have so much experience in this agrobusiness. }\end{array}$ \\
\hline & Training and education & $\begin{array}{l}\text { Canada just recently legalized marijuana and the Canadian marijuana industry } \\
\text { is picking up all the growers. Therefore, we go straight to the universities to get } \\
\text { people. But at the end we don't have problems with finding people who are really } \\
\text { excited to work for us, so it is not a problem. }\end{array}$ \\
\hline \multirow[t]{3}{*}{ Future perspectives } & Future market composition & $\begin{array}{l}\text { It is a booming business and there will be a lot of larger companies and } \\
\text { participants, but a lot of them will disappear and some will succeed. The ones that } \\
\text { will succeed will be really big. It's only going to work if you are able to grow all } \\
\text { crops and on very large scales. }\end{array}$ \\
\hline & Technology & $\begin{array}{l}\text { Cutting the price of LEDs, involvement of new areas joining the VF/CEA industry, } \\
\text { micro energy devices, better energy systems, all aspects that are really important. } \\
\text { Biomass is a good solution for energy but that is really hard to do in a city or } \\
\text { urban area. }\end{array}$ \\
\hline & Specification and differentiation & $\begin{array}{l}\text { They have the potential for diversified food production on a local level with a } \\
\text { small footprint. }\end{array}$ \\
\hline
\end{tabular}


APPENDix 2. Map of interviewees.

\begin{tabular}{|c|c|c|c|c|}
\hline ID & Location & Company & Industry experience & Function \\
\hline CA-VF1 & Canada & VF/Indoor farm & $<5$ & Top management \\
\hline EU-P1 & Europe & Consultancy & $>20$ & Top management \\
\hline EU-P2 & Europe & Research & $<5$ & Business developer \\
\hline EU-P3 & Europe & Industry support & $>20$ & Top management \\
\hline EU-P4 & Europe & Investments \& research & $>15-20$ & Produce industry analyst \\
\hline EU-P5 & Europe & Industry support & $<5$ & Top management \\
\hline EU-VF1 & Europe & VF/Indoor farm & $<5$ & Top management \\
\hline EU-VF2 & Europe & VF/Indoor farm & $>20$ & Top management \\
\hline EU-VF3 & Europe & VF/Indoor farm & $<5$ & Top management \\
\hline EU-VF4 & Europe & VF/Indoor farm & $\geq 5-10$ & Top management \\
\hline EU-VF5 & Europe & VF/Indoor farm & $<5$ & Top management \\
\hline EU-VF6 & Europe & VF/Indoor farm & $<5$ & Researcher \\
\hline US-P1 & USA & Research & $<5$ & Research \& management \\
\hline US-P2 & USA & Consultancy & $\geq 5-10$ & Top management \\
\hline US-P3 & USA & Research & $<5$ & Researcher \\
\hline US-P4 & USA & Research \& training & $\geq 5-10$ & Top management \\
\hline US-P5 & USA & Research & $>20$ & Researcher \\
\hline US-P6 & USA & Technology \& systems & $>15-20$ & Business developer \\
\hline US-P7 & USA & Technology \& systems & $<5$ & Sales \\
\hline US-P8 & USA & Industry support & $>15-20$ & Government agency \\
\hline US-VF1 & USA & VF/Indoor farm & $\geq 5-10$ & Senior advisor \\
\hline US-VF2 & USA & VF/Indoor farm & $<5$ & Top management \\
\hline US-VF3 & USA & VF/Indoor farm & $\geq 5-10$ & Top management \\
\hline US-VF4 & USA & VF/Indoor farm & $<5$ & Researcher \\
\hline US-VF5 & USA & VF/Indoor farm & $\geq 5-10$ & Top management \\
\hline
\end{tabular}


International Workshop on Vertical Farming

13-15 October 2019

Wageningen, The Netherlands

Sponsored by
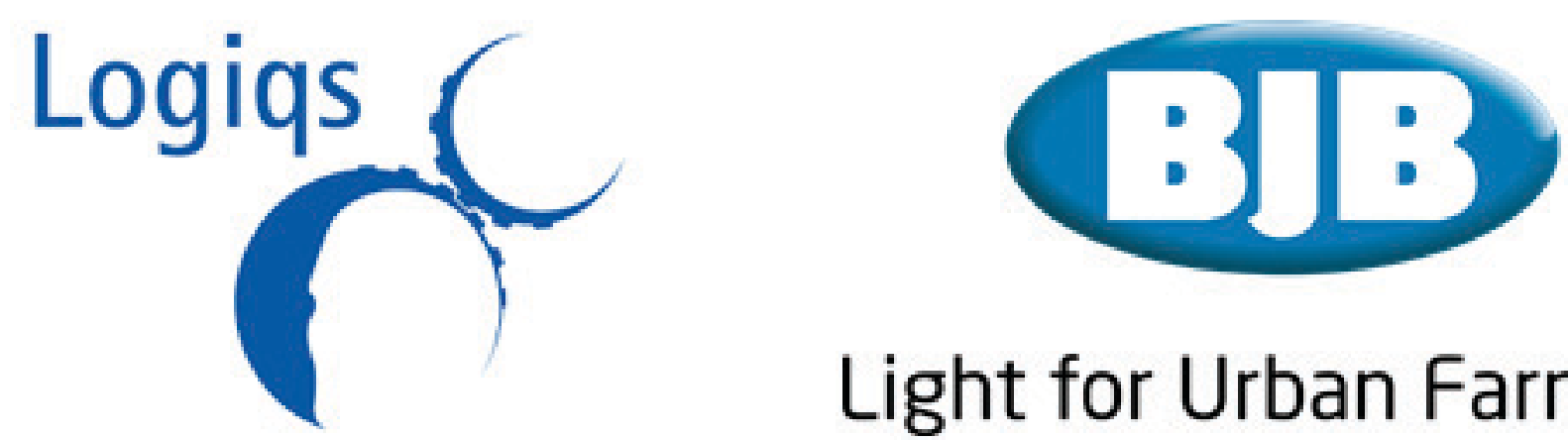

\section{Light for Urban Farming}

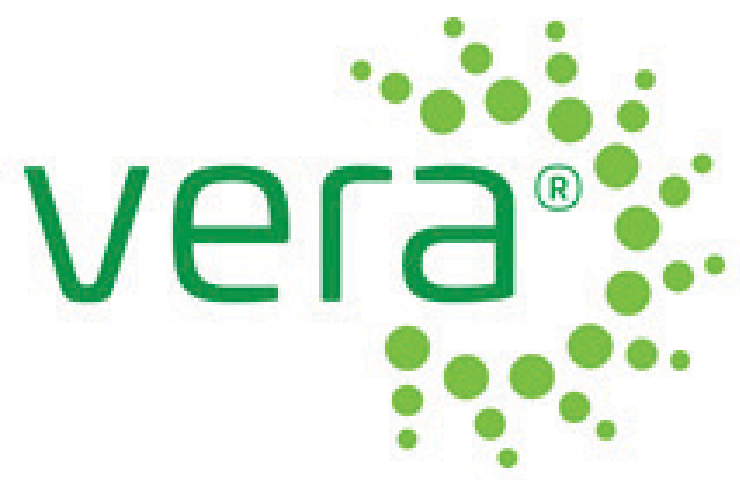

Nouryon

\section{Chelated} Micronutrients
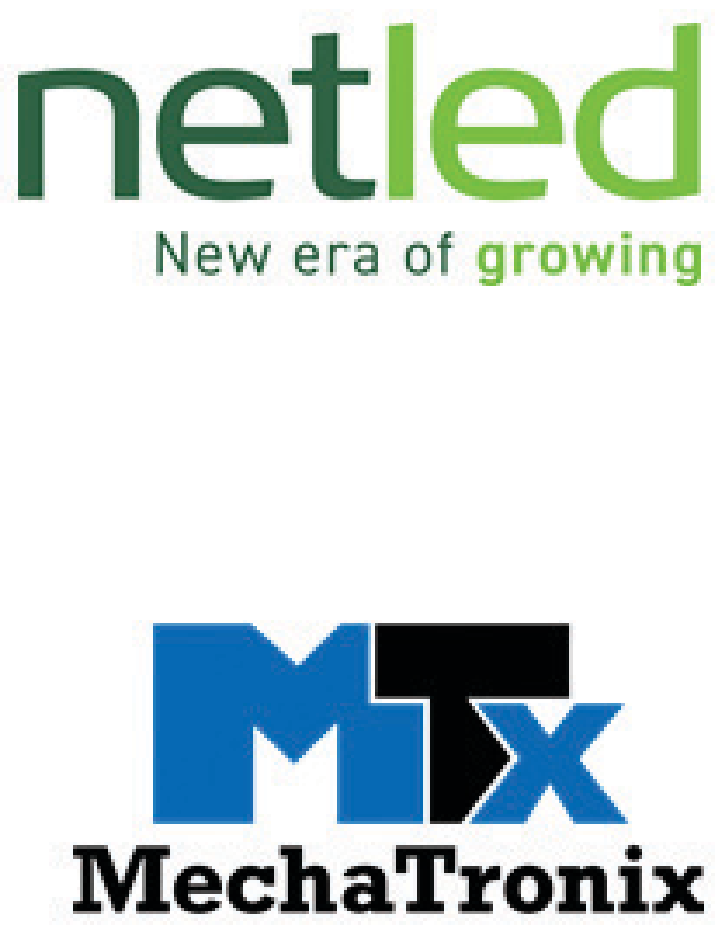

Fடㅁㅁய

$$
\text { F L U E N C E }
$$

